\title{
PEMBUATAN SPEKTROFOTOMETRI VISIBEL 470 nm MENGGUNAKAN ARDUINO UNO R3
}

\author{
Manufacturing Spektrofotometri Visibel 470 Nm Using Arduino Uno R3 \\ Yohan
}

Jurusan Teknik Mesin, Universitas Pamulang, 45363 Pamulang, Tangerang Selatan, Indonesia

E-mail : yohan_nk07@yahoo.co.id

\begin{abstract}
ABSTRAK
Spektrofotometri sederhana ini terdapat photodiode untuk referensi dan sampel. Sampel yang digunakan pada penelitian ini adalah pewarna makanan komersial berwarna merah berbahan dasar karmoisin (Azorubin) dan tembaga sulfat (CuSO4). Pada kotak hitam sumber cahaya ini diberikan daya 24 watt dengan arus 2 A yang disesuaikan terhadap power supply dan temperatur operasional sekitar $27 \mathrm{oC}$. Spektrofotometer memberikan hasil pengukuran yang cukup baik, pada uji karmosin pada konsentrasi 100-1200 ppm menghasilkan persamaan y =0,114x dengan koefisien korelasi 0,984 dan memiliki RSD 0,0176. Pada spektrofotometer sederhana ini memiliki akurasi dan presisi sebesar $95,35 \%$ dan $99,35 \%$.
\end{abstract}

Kata kunci: Spektrofotometri, Arduino, Karmosin.

\section{ABSTRACT}

Simple spectrophotometry consist of reference photodiode and sample. Sample was used in this investigation such as red dyes for food based on carmosine (Azorubin) and cuprum sulphate (CuSO4). Radiasi source in black was working on 24 watt with current 2 A which setting on power supply properly, then operational temperature was approxymatelly $27 \mathrm{oC}$. Spectrophotometry presented the best result at range 100 to 1200 ppm of carmosine with linierity $y=0,114 x$, regression coefisien 0,984 and RSD 0,0176. Simple spektrofotometer produced accuration and precision about 95,35\% and 99,35\%.

Keywords: Spectrophotometer, Arduino, Carmosine.

\section{PENDAHULUAN}

Peralatan laboratorium merupakan unit fungsional terkecil di laboratorium untuk pengembangan suatu bidang ilmu. Suatu lembaga pendidikan yang berbasis sains tidak dapat maju jika mengabaikan keberadaan alat laboratorium. Keberadaan alat laboratorium kimia sangat penting di dalam suatu lembaga pendidikan, terutama di pendidikan tinggi untuk dapat mewujudkan pengembangan dan pemanfaatan ilmu kimia secara sinambung. Namun, sampai saat ini kebutuhan pemenuhan alat laboratorium masih terbatas. Spektrofotometer merupakan instrumen penting dalam analisis kimia yang digunakan untuk menguji sampel tertentu yang berorientasi pada pengukuran kepekatan warnanya. Instrumen ini penting digunakan pada sektor pendidikan, penelitian, maupun industri.

Pada sektor pendidikan alat ini sebagai media pendidikan untuk meningkatkan pemahaman mahasiswa pada pengenalan alat dan praktikum. Pada sektor penelitian berperan dalam menguji analisis senyawa 


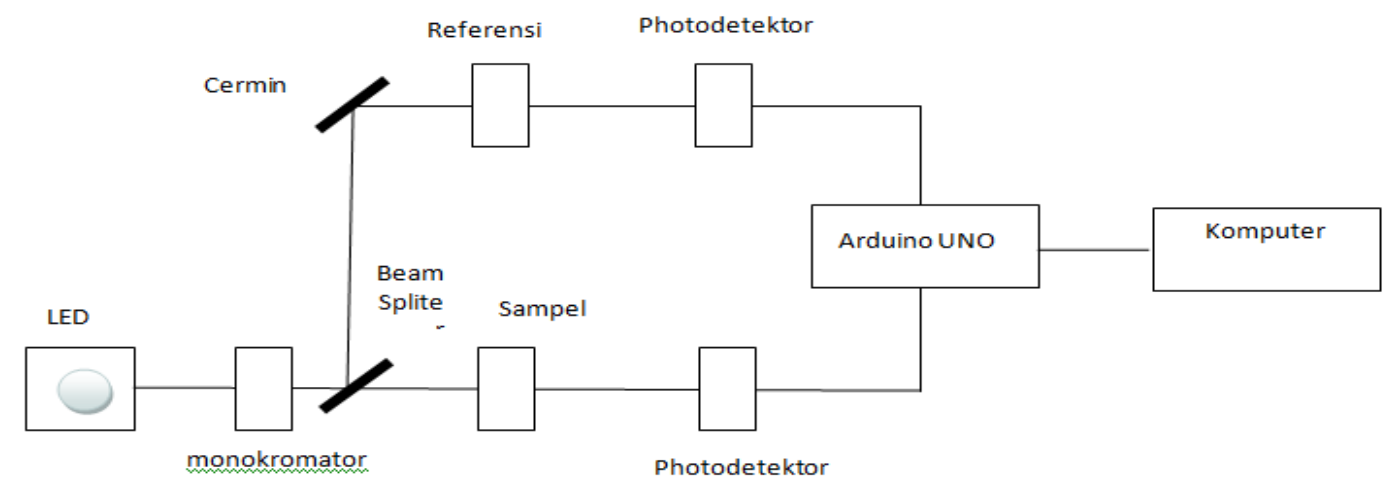

Gambar 2.1. Desain Sistem Spektrofotometer sederhana [2].

secara kuantitatif dan kualitatif pada sampel. Pada sektor industri alat ini berperan untuk menentukan kadar bahan yang digunakan pada industri pigmen dan analisis kadar senyawa pada limbah yang dihasilkan. Namun untuk pemenuhan alat ini, negara Indonesia masih mengimport dari negara lain. Adapun Daniel dan rekannya telah mengembangkan spektrofotometer dengan biaya murah menggunakan empat LED [1]. Yeh dan Tseng membuat spektrofotometer seharga 20 dollar menggunakan LED variasi warna dan mendisain low-cost spektrofotometer double beam [2]. Oleh karena itu, Penulis berproyeksi mengembangkan spektrofotometer dengan biaya murah menggunakan LED dan arduino. Harapannya dengan pengembangan produk ini, dalam jangka pendek produk ini akan memudahkan analisis uji sampel penelitian dan terjangkau baik lembaga pendidikan dan penelitian yang terkait. Dalam jangka panjang akan terjadi pengembangan instrument lain yang terkait.

\section{BAHAN DAN METODE}

Alat yang digunakan untuk transmitter sinyal ke display adalah Arduino UNO R3 dan laptop untuk display sensor. Bahan yang digunakan adalah pewarna makanan, akuabides, CuSO4, kuvet, LED, photodetektor TSLG257, PCB, Kabel, resin fiberglass, silikon rubber RTV.

\section{Desain Perancangan spektrofotometer sederhana}

Desain Perancangan Spektrofotometer Sederhana sebagai berikut:

\section{Uji Linearitas, Penentuan Sensitivitas dan Batas Deteksi.}

Uji linearitas, penentuan sensitivitas, batas deteksi, dan batas kuantifikasi dilakukan sesuai prosedur, di mana dilakukan tiga kali pengulangan terhadap masing-masing prosedur pada variasi konsentrasi tembaga sulfat $0,0,1,0,3,0,5$, dan 0,9 M dan karmosin 100- 1200 ppm.

\section{Penentuan Kecermatan dan Ketepatan}

Kecermatan dan ketepatan ditentukan dengan melakukan pengukuran sebanyak tiga kali pengulangan terhadap larutan standar seperti yang telah dijelaskan pada prosedur. Dari hasil pengukuran diperoleh rata-rata puncak arus dan simpang baku pengukuran. Kecermatan dinyatakan dalam simpang baku relatif (relative standard deviation / RSD), sedangkan ketepatan dinyatakan dalam persen galat relatif (\% relative error $/ \% \mathrm{E}$ ). 


\section{HASIL DAN PEMBAHASAN}

\section{Pembuatan spektrofotometer sederhana}

Pembuatan spektrophotometer sesuai dengan sistem doubel beam. Spektrofotometri sederhana ini terdapat photodiode untuk referensi dan sampel. Sampel yang digunakan pada penelitian ini adalah pewarna makanan komersial berwarna merah berbahan dasar karmoisin (Azorubin) [3] dan tembaga sulfat $\left(\mathrm{CuSO}_{4}\right)$. Warna merah memberikan nilai absorpsi panjang gelombang maksimum sekitar $460 \mathrm{~nm}$. Panjang gelombang cahaya (ג) lampu biru adalah 465-470 $\mathrm{nm}$ yang memungkin untuk perhitungan absorbansi dihubungkan dengan besarnya voltase terhadap transmitansi cahaya yang dilalui sampel.

Pada Gambar 2.1. menunjukkan sistem spektrofotometer visibel. Pada spektrofotometer visibel ini menggunakan sistem double beam dimana intensitas cahaya referensi $\left(\mathrm{I}_{\mathrm{o}}\right)$ dapat dibandingkan dengan intensitas cahaya setelah melewati sampel $\left(\mathrm{I}_{\mathrm{t}}\right)$. sumber cahaya megunakan jenis SMD LED berwarna biru mempunyai panjang gelombang 465-470 $\mathrm{nm}$ [4]. LED didesain didalam kotak hitam yang terbuat dari material fiberglass yang diberikan split cahaya diameter sekitar $5 \mathrm{~mm}$ untuk referensi dan sampel. Arduino Uno R3 diinstalasi pada pin 2 , potensial $5 \mathrm{VDC}$, dan grounding pada masing-masing PCB photodiode. Dimensi spekrofotometer visibel sederhana berdimensi $6,5 \mathrm{~cm} \times 9,5 \mathrm{~cm} \times 10 \mathrm{~cm}$ yang terbuat dari bahan faiberglass berwarna hitam dengan cetakan yang telah didisain sesuai dengan ukuran mini. Program software arduino uno R3 diinstal pada mode arduino 1.6.12.

\section{Pembuatan Kotak Hitam Sumber Cahaya} $\begin{aligned} & \text { Pembuatan } \text { Kotak hitam sumber } \\ & \text { cahaya dibuat untuk mempermudah }\end{aligned}$ mengganti panjang gelombang sesuai yang diinginkan dalam menganalisa suatu senyawa pada absorbansi tertentu pada spektrum visibel. Pada kotak hitam dilapisi dengan aluminum untuk menghindari cahaya tembus pada kotak yang dapat memberikan inteferensi pada proses pengukuran.

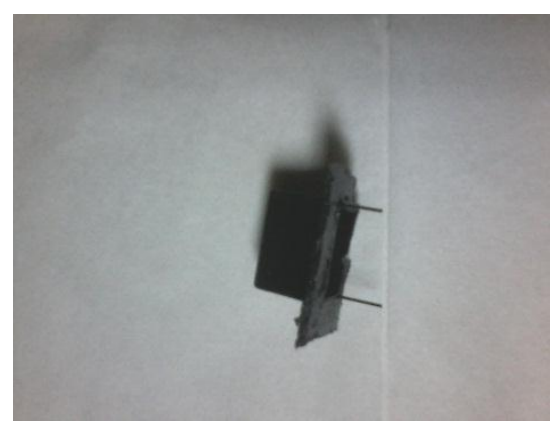

Gambar 3.1. Hasil Pembuatan Kotak hitam Sumber Cahaya

Kotak hitam LED dibuat dengan dimensi $1 \mathrm{~cm} \times 1,5 \mathrm{~cm} \times 2 \mathrm{~cm}$ dengan ketebalan $20 \mathrm{~mm}$ yang terbuat dari bahan fiberglass dan pewarna hitam agar mengurangi inteferensi cahaya dari luar. Pada kotak hitam sumber cahaya ini diberikan daya 24 watt dengan arus 2 A yang disesuaikan terhadap power supply dan temperatur operasional sekitar $27^{\circ} \mathrm{C}$.

\section{Pembuatan rangka spektrofotometer sederhana}

Pada spektrofotometer sederhana ini dilengkapi dengan temperatur lingkungan,

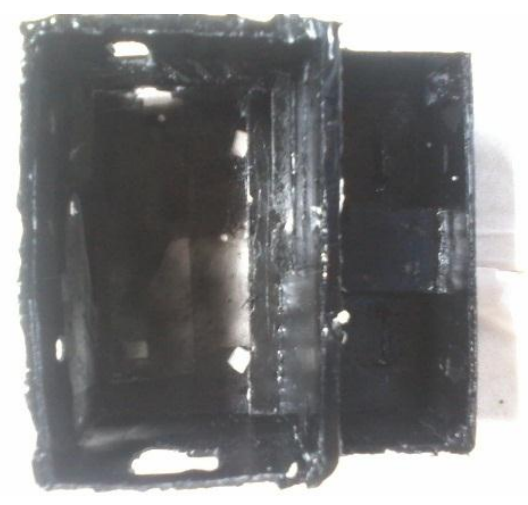


Gambar 3.2. Hasil Pencetakan rangka spektrofotometer sederhana.

sehingga dapat diamati jika terdapat pengaruh temperatur terhadap absorbasi molekul yang diamatin. Dimensi spekrofotometer visibel sederhana berdimensi $6,5 \mathrm{~cm} \times 9,5 \mathrm{~cm} \times 10 \mathrm{~cm}$ dengan tebal $20 \mathrm{~mm}$. pada disain rangka spektrofotometer sederhana ini dilengkapi dengan slot soket untuk power supply dan arduino sehingga plug bisa dilepas pasang tidak terikat secara permanen.

\section{Perakitan spektrofotometer sederhana}

Pada spektrofotometer sederhana ini terdiri dari jalur power suplly untuk sumber arus dan jalur arduino menuju komputer. Pada alas bawah rangka diletakkan ardiono UNO R3 hal ini bertujuan agar arduino tidak mengalamin gangguan pada saat operasi dan mempermudah operasi apabila terjadi gangguan. Arduino Uno adalah board berbasis mikrokontroler pada ATMega 328. Board ini memiliki 14 digital input / ouput pin (dimana 6 pin dapat digunakan sebagai ouput PWM), 6 input analog, $16 \mathrm{MHz}$ osilator kristal, koneksi USB, jack listrik dan tombol reset. Pin - pin ini berisi semua yang diperlukan untuk mendukung mikrokontroler, hanya terhubung ke komputer dengan kabel USB atau sumber tekanan bisa didapat dari adaptor AC - DC atau baterai untuk menggunakannya [5-6]. Power supply digunakan pada spektrofotometer sederhana ini digunakan memiliki potensial $12 \mathrm{~V}$ dan arus $2 \mathrm{~A}$ yang sesuai terhadap sumber cahaya untuk operasional.

Warna berasal dari absorpsi cahaya visibel, ketika molekul mengabsorbsi foton atau kuantum cahaya terjadi perbedaan antara molekul awal dan molekul yang tereksitasi
[7]. Pada umumnya tingkat energi ini termasuk dalam keadaan rotasi, vibrasi, dan

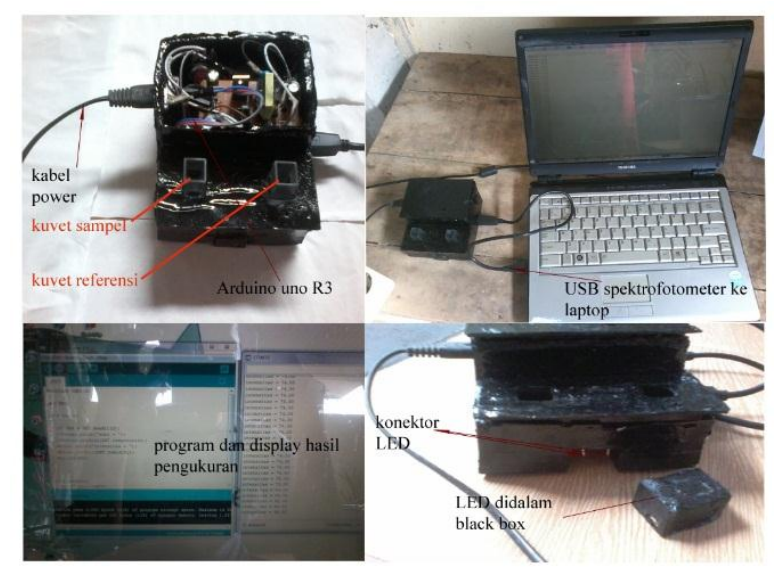

Gambar 3.3. Pembuatan Spektrofotometer sederhana dan program Arduino

energi elektron di dalam molekul. Foton pada cahaya visibel diabsorbsi dan mengeksitasi molekul dari konfigurasi dasar (energi terendah) kekonfigurasi elektron energi tertinggi. Transisi antara konfigurasi elektron, atau keadaan elektronik, sangat berpengaruh terhadap warna yang terlihat [8]

Pada spektrofotometer sederhana ini memberikan respon yang baik terhadap sumber cahaya terhadap photodiode. Pada desain spektrofotometer visibel sederhana ini mempunyai dua penutup yaitu penutup PCB rangkaian dan penutup bagian kuvet yang terbuat dari fiberglass berwarna hitam dan warna hitam bertujuan untuk mengurangi intensitas cahaya luar yang masuk kedalam sistem yang dapat menimbulkan interferensi pada pengukuran. Pengoperasian spektrofotometer visibel sederhana untuk sumber cahaya diberikan daya \pm 24 Watt kemudian pembacaan absorbansi pada transduser ditampilkan pada display PC yang telah diinstal arduino 1.6.12.

Uji linieritas dan batas deteksi pada karmosin menggunakan spektrofotometri sederhana 
Spektrofotometer visibel sederhana yang telah didesain selanjutnya dilakukan uji liniearitas untuk mengatahui kinerja alat pengukuran spektrometer ini. Uji linieritas dilakukan dengan cara membuat larutan pewarna makanan komersial karmosin merah yang mempunyai konsentrasi $100-1200$ ppm .

Spektrofotometer visibel sederhana yang telah didesain selanjutnya dilakukan uji liniearitas untuk mengatahui kinerja alat pengukuran spektrometer ini. Uji linieritas dilakukan dengan cara membuat larutan pewarna makanan komersial karmosin merah yang mempunyai konsentrasi $100-1200$ ppm .

Pada pengukuran sistem doubel beam yang memiliki pengukuran terhadap sampel dan referensi. Bahan referensi yang digunakan adalah aquades sebagai blanko. Dimana pada sistem aquades akan memberikan nilai 0 yang berarti tidak adanya

kadar karmosin didalam referensi sehingga dapat digunakan sebagai pembanding dalam satu kali pengukuran yang diulang sebanyak tiga kali. Berdasarkan hasil pengukuran dari konsentrasi 100 - 1200 ppm, spektrofotometer memberikan hasil

Tabel 3.1. Hasil pengukuran konsentrasi karmosin merah terhadap absorbansi menggunakan spektrofotometri sederhana.

\begin{tabular}{cccc}
\hline No & $\begin{array}{c}\text { Konsentrasi } \\
(\mathbf{p p m})\end{array}$ & Absorbansi & $\begin{array}{c}\text { Temperatur } \\
\left({ }^{\circ} \mathbf{C}\right)\end{array}$ \\
\hline 1 & 0 & 0 & 27 \\
2 & 115 & 0.010219 & 27 \\
3 & 254 & 0.020685 & 27 \\
4 & 762 & 0.065285 & 27
\end{tabular}

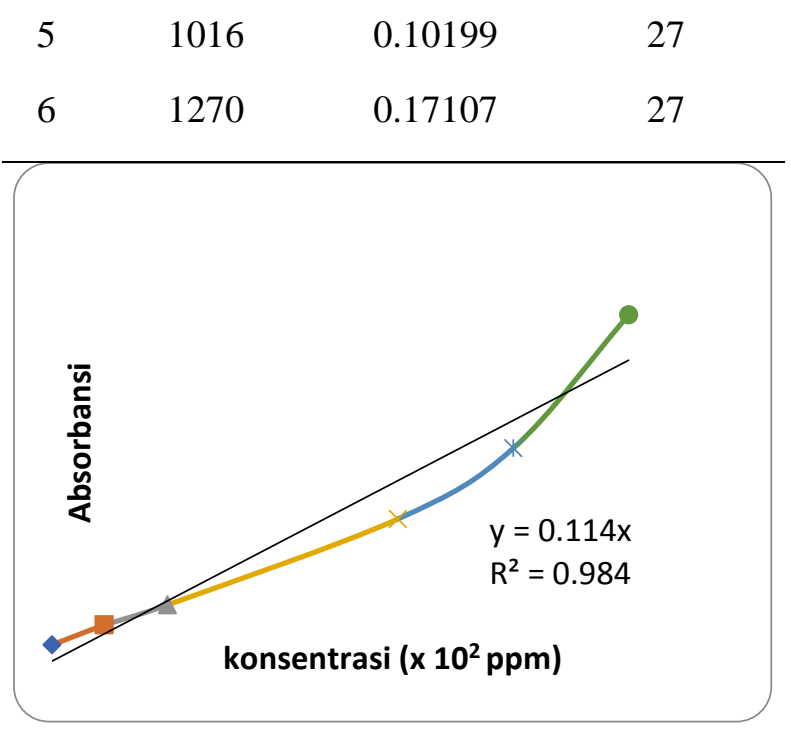

Gambar 3.4. Grafik hubungan konsentrasi karmosin 100-1200 ppm terhadap absorbansi pada pengukuran menggunakan spektrofotometer sederhana.

pengukuran yang cukup baik hal ini ditujukkan pada Tabel 3.1. yang menunjukkan kenaikan konsentrasi sebanding dengan kenaikan absorbansi.

Perhitungan absorbasi dilakukan dengan menggunakan persamaan 1 dan 2 berdasarkan hukum lambert-beer [8,9]. Pada uji ini dihasilkan persamaan $\mathrm{y}=0,114 \mathrm{x}$ dengan koefisien korelasi 0,984. Batas kepercayaan intersep dengan $\mathrm{db}=4$, rentang kepercayaan $95 \%, \mathrm{t}=2,78$ yaitu 0,0470 sampai 0,1863 dan rentang kepercayaan intersept yaitu $-0,0397$ sampai 0,0229 dan memiliki RSD 0,0176. Batas konsentasi terendah yang terdeteksi dilakukan secara manual dengan mencoba memberikan konsentrasi dibawah 80 ppm karmosin memberikan nilai absorbansi sama dengan nilai absorbansi 100 ppm. Kemudian untuk 50 ppm karmosin memberikan nilai absorbansi nol (sama dengan blanko). Pada penentuan nilai presisi dan akurasi dilakukan enam kali perulangan pengukuran dan menggunakan persamaan [10]. Hasil terbaik didapatkan nilai presisi 99,35\% dan untuk 
nilai akurasi dilakukan menggunakan larutan standar dengan menggunakan konsetrasi 1000 ppm dengan enam kali perulangan sehingga didapatkan nilai akurasi 95,82\%.

\section{KESIMPULAN}

Spektrofotometri sederhana dirancang berdimensi $6,5 \mathrm{~cm} \times 9,5 \mathrm{~cm} \times 10 \mathrm{~cm}$ yang terbuat dari bahan fiberglass dengan menggunakan sumber cahaya dari LED berwarna biru dengan panjang gelombang 465-470 nm dan dilengkapi dengan sensor temperatur. Pada pengukuran menggunakan spektrofotometri sederhana memberikan hasil pengukuran yang baik, nilai absorbansi sebanding dengan nilai konsentrasi analit. Uji linearitas pada spektrofotometri sederhana ini didapatkan nilai terbaik pada pengukuran menggunakan analit karmosin menghasilkan persamaan $\mathrm{y}=0,114 \mathrm{x}$ dengan koefisien korelasi 0,984 dan batas konsentasi terendah yang terdeteksi 80 ppm, sedangkan untuk 50 ppm karmosin memberikan nilai absorbansi nol (sama dengan blanko). Pada spektrofotometer sederhana ini memiliki akurasi dan presisi sebesar 95,35\% dan $99,35 \%$ sehingga dapat diasumsikan sepektrofotometer berbasis arduino ini memiliki kelayakan sebagai alat pengukuran alternatif pada spektrofotometer Vis.

\section{UCAPAN TERIMAKASIH}

Penulis mengucapkan terimakasih kepada LPPM UNPAM untuk bantuan dana pada penelitian ini .

\section{DAFTAR PUSTAKA}

[1] Daniel, R. A., Michael, A.T., Davis, H.F.( 2012 ). A Low-Cost Quantitative Absorption Spectrophotometer. J.Chem. Educ.89. pp.1432-1435.
[2] Gong,W., Mowlem, M., Kraft, M., Morgan, H. (2009) A simple low-cost double beam spectrophotometer for colorimetric detection of nitrite in sea water. ISSE sensor jounal:7 (862-869).

[3] Montaser, M. \& Alkafafy, M. (2013). Effect of synthetic food color (carmosine) on expression of some fuel metabolism genes in liver of male albino rats. Life sains journal.(10) : 2191-21981097.

[4] An. (2016) Flexible LED strips light specification. www.ledlightsworld.com. Diakses tanggal 20 Desember 2016.

[5] Massimo, B.(2011) Getting Started with Arduino second edition. O'Reilly. ISBN : 978-1- 449-309879.

[6] Savasgard, E.(2014). Arduino 101 beginers guide. Independent publishing platform. ISBN : 1516964624

[7] Jim, C.(2013). The Colors of Complex Metal Ions. Chem guide Publishing. http://www.chemguide.co.uk/inorganic/c omplexions/colour.html, diakses 25-092016.

[8] Solvason, G. (2015) Master of Science Thesis, Mechanical Engineering, Reykajavic University, Iceland.

[9] Ahmed, A. F., Ayman, H.Z., Mohamed, H.K. (2016) Control of Selectivity in Heterogeneous Photocatalysis by Tuning TiO2 Morphology for Water Treatment Applications. ResearchGate. DOI: 10.5772/62296.2016.

[10] Caulcutt, R. \& Boddy, R.(1983) Statistics for Analitical Chemsist. Chapman and Hall. London. ISBN: $041223730 \mathrm{X}$. 